\title{
Inheritance of Antioxidant Activity and its Association with Seedcoat Color in Cowpea
}

\author{
M. Ndambe Nzaramba1, Anna L. Hale², Douglas C. Scheuring' ${ }^{3}$, and J. Creighton Miller, Jr. ${ }^{4}$ \\ Department of Horticultural Sciences, Texas A\&M University, College Station, TX 77843-2133
}

\begin{abstract}
AdDitional INDEX WORDS. southernpea, combining ability, diallel mating design, heritability, scaling test, maternal effects, pleiotropy, DPPH

Abstract. The inheritance of antioxidant activity (AOA) and its association with seedcoat color was investigated in cowpea [Vigna unguiculata (L.) Walp.]. Four advanced cowpea lines, ARK95-356 (black seedcoat) and ARK98-348 (red seedcoat), which were high (H) in AOA, and ARK96-918 (cream seedcoat) and LA92-180 (cream seedcoat), which were low (L) in AOA, were selected from the 2002 Regional Southernpea Cooperative Trials. They were crossed in a complete diallel mating design, generating $\mathrm{F}_{1}, \mathrm{~F}_{1}{ }^{\prime}\left(1 \mathrm{st}\right.$ generation and 1 st generation reciprocal cross, respectively), $\mathrm{F}_{2}$, $\mathrm{F}_{2}^{\prime}$ (2nd generations from $\mathrm{F}_{1}, \mathrm{~F}_{1}^{\prime}$ ), $\mathrm{BC}_{1}$, and $\mathrm{BC}_{2}$ (backcrosses to parents 1 and 2 , respectively) populations. Individual seeds were ground and samples were extracted in methanol and analyzed for AOA using the free radical 2,2-diphenyl-1-picrylhydrazyl (DPPH) method. Combining ability tests using Griffing's Method I Model I indicated presence of highly significant general combining ability (GCA), specific combining ability (SCA), and reciprocal (RE) and maternal (MAT) effects, with pigmented lines exhibiting positive GCA and MAT, while nonpigmented lines exhibited negative GCA and MAT. AOA in the $F_{1}$ was not significantly different from the maternal parent, with seedcoat color also resembling the maternal parent. Segregation for seedcoat color was observed in the $F_{2}$ and $F_{2}{ }_{2}^{\prime}$. Additive, dominance, and epistatic effects were significant. The broad sense heritability estimate was 0.87 . Minimum number of genes responsible for $\mathrm{AOA}$ was estimated at five. Factors governing high $\mathrm{AOA}$ appeared to be the same as those responsible for seedcoat color, with apparent pleiotropic effects. In conclusion, breeding for high AOA in cowpea is possible using highly pigmented parental lines.
\end{abstract}

Cowpea is one of the most ancient food sources, cultivated throughout the world primarily as a pulse and vegetable. It is broadly adapted and grown successfully in extreme environments such as high temperature and low rainfall, and does well on poor soils with few economic inputs. Cowpea is a nutritious source of food, providing proteins, vitamins, minerals, and carbohydrates. The protein profile complements roots, tubers, or cereals, especially in areas where the population cannot afford higher protein foods such as meat.

Several legumes, cowpea included, have been found to contain non-nutrient, bioactive phytochemicals that possess antioxidant capabilities (Beninger et al., 1998; Messina, 1999; Narasinga Rao, 1995; Nzaramba et al., 2003; Warrington et al., 2002). Antioxidants are compounds that inhibit or delay the oxidation of other molecules by inhibiting the initiation or propagation of oxidizing chain reactions (Klein and Kurilich, 2000; Velioglu et al., 1998). The Food and Nutrition Board of the National Academy of Science (1998) defined dietary antioxidants as substances in foods that significantly decrease the adverse effects of reactive oxygen species, reactive nitrogen species, or both on normal physiological function in humans.

Antioxidant activity (AOA) is a fundamental property important for life. Antioxidants with versatile functions constitute a complex network to overcome oxidative stress suffered by aerobic organisms. Under certain circumstances, however, the natural defenses can be insufficient resulting in health problems, hence making administration of exogenous antioxidants as food constituents or therapeutic agents necessary and beneficial (Niki

Received for publication 5 May 2004. Accepted for publication 13 Sept. 2004. This paper is a portion of a thesis submitted by M.N.N.

${ }^{1}$ Graduate Student.

${ }^{2}$ Graduate Student. Current address: U.S. Vegetable Laboratory, ARS, USDA, 2700 Savannah Highway, Charleston, SC 29414.

${ }^{3}$ Senior Research Associate.

4Professor.Towhom reprint requests should be addressed.E-mail: jcmillerjr@tamu. edu and Noguchi, 2000). Investigations have suggested that diets rich in antioxidant compounds are associated with longer life expectancy (Hertog and Hollman, 1996). These compounds have many health-related properties such as anticancer, antiviral, and anti-inflammatory effects, and ability to inhibit human platelet aggregation (Benavente-Garcia et al., 1997; Cook and Samman, 1996; Huang and Ferraro, 1992), raising interest among scientists, food manufacturers, and consumers, as the trend of the future is moving toward functional foods with specific health effects (Robards et al., 1999; Velioglu et al., 1998).

Synthetic antioxidants such as butylated hydroxyanisole (BHA) and butylated hydroxytoluene (BHT) have been used as antioxidants since the beginning of the 20th century; however, restrictions on their use are being imposed because of their suspected carcinogenicity (Barlow, 1990; Branen, 1975; Chang et al., 2002; Ito et al., 1983). There is, therefore, a trend to replace these synthetic antioxidants with naturally occurring antioxidants (Koleva et al., 2002). Natural antioxidants are present in foods as endogenous constituents (Shahidi, 2002). Efforts are being undertaken to isolate, characterize and extract these compounds from plant sources (Morello et al., 2002). Plants vary in composition of phytochemicals with concomitant protective functions. Hence, for maximum health benefits, sufficient amounts of phytochemicals from a variety of sources such as fruit, vegetables, legumes, and whole grain-based foods are recommended.

Many studies have associated phenolic antioxidants with the color pigments of food plants. Comis (2000) stated that consumers who pay attention to the colors of foods they cook and serve are enhancing not only visual and gustatory pleasure, but nutritional effects as well. Amarowicz et al. (1996) indicated that extracts obtained from five species of legumes with colored seedcoat, pea (Pisum sativum L.), faba bean (Vicia faba L.), lentil (Lens culinaris Medik.), and everlasting pea (Lathyrus latifolius L.), were characterized by high AOA. They also concluded that antioxidant substances in legumes were present mainly in the 
seedcoat. In earlier studies, while evaluating variability for AOA in the Regional Southernpea Cooperative Trials, it was observed that high AOA appeared to be associated with dark seedcoat color (Warrington et al., 2002). Troszyńska et al. (2002) reported that extracts from $P$. sativum seedcoats exhibited pronounced AOA. They concluded that phenolic substances occurring in the seedcoat of colored pea cannot be neglected as a source of antioxidants. Some types of peas with colored seedcoats have a strong or astringent flavor, granular texture, and dark liquor when cooked, making then unpopular (Fery, 1985).

The challenge and responsibility for horticulturists is to design approaches to improve the nutritional quality and visual appeal of the food supply in order to provide a sustainable, inexpensive complement to medical and social programs that are striving to prevent human diseases (Simon, 1997). This can be achieved through developing crops that provide significant amounts of antioxidants. In order to breed for increased AOA in cowpea seeds, determination of the inheritance of AOA is necessary. Also, ascertaining the genetic relationship between AOA and seedcoat color would help breeders improve cowpea varieties while keeping in mind color preferences of consumers. The principal aim of this research was to elucidate the genetics governing AOA in cowpea seeds, which could therefore be utilized to improve cowpea varieties for this trait. The objectives of the study were to: 1) elucidate the nature of the inheritance of AOA in cowpea seeds by estimating heritability, number of genes involved, their additive and dominance effects, and nonallelic effects, and 2) further investigate the relationship between AOA and seedcoat color.

\section{Materials and Methods}

Plant Material. Advanced lines in the 2002 Regional Southernpea Cooperative Trials were evaluated for AOA (results not shown). Four lines with extreme levels of AOA, ARK96-918, LA92-180, ARK98-348, and ARK95-356 were selected as parental lines for this study. Parental lines were planted in the greenhouse at College Station, Tex., in Fall 2002. Seeds were inoculated with Nitragin (LiphaTech, Milwaukee) and planted in 7.6-L plastic pots filled with Metro-mix 366 (Scotts-Sierra, Marysville, Ohio) growing medium. The pots were arranged in a completely randomized block design (Lentner and Bishop, 1993), consisting of three blocks with five pots per block and four seeds per pot. After germination, seedlings were thinned to two plants per pot.

Crosses were made between the parental lines (Table 3 ) in all possible combinations, including reciprocals, forming a $4 \times$ 4 complete diallel design (Griffing, 1956). $\mathrm{F}_{1} \mathrm{~s}$ and reciprocals, together with their parents from each block, were harvested and bulked. Thirty seeds were randomly chosen from $F_{1}$ and reciprocal populations for antioxidant analysis. The remaining $\mathrm{F}_{1}$, reciprocals, and parental seeds were planted in the greenhouse during the Spring 2003. Backcrosses were made at the same time, allowing $\mathrm{F}_{1}$ s to self, generating $\mathrm{F}_{2}$ and $\mathrm{F}_{2}^{\prime}$ populations.

SAMPLE EXTRACTION. Thirty individual seed samples selected randomly from parental, $\mathrm{F}_{1}$ and reciprocals, and 200 seeds selected from each of the segregating populations (i.e., $\mathrm{BC}_{1}, \mathrm{BC}_{2}$, and $\mathrm{F}_{2}$ ) were analyzed. Individual seeds were ground with a Braun KSM2 (Braun U.S. Div., Boston) coffee grinder. The product was transferred to a porcelain mortar and further ground to a fine powder. The powder was weighed and placed in $1.5-\mathrm{mL}$ microcentrifuge tubes. One milliliter of high-pressure liquid chromatography (HPLC)-grade methanol was added to each sample, homogenized using a laboratory mixer, and centrifuged for $15 \mathrm{~min}$ at 23,660 $g_{\mathrm{n}}$ using a Biofuge 13 microcentrifuge (Heraeus Instruments, South Plainfield, N.J.).

DPPH ASSAY. Total AOA of the sample extracts was analyzed using DPPH (Brand-Williams et al., 1995), a stable radical with strong oxidizing capacity. The DPPH methanol solution is dark purple in color and when reacted with an antioxidant the color fades. The change in color was measured as a reduction in absorbance using a spectrophotometer. The DPPH assay was prepared by dissolving $24 \mathrm{mg}$ of DPPH in $100 \mathrm{~mL}$ of HPLC-grade methanol. The solution was diluted several times with methanol until its absorbance was 0.5 units at $515 \mathrm{~nm}$ on a Shimadzu Biospec-1601 (Shimadzu Scientific Instruments, Columbia, Md.) spectrophotometer. One hundred fifty microliters of supernatant were pipetted into a scintillation vial in which $2850 \mu \mathrm{L}$ of methanolic DPPH solution was added and left to react for $15 \mathrm{~min}$ on a shaker. The mixture was transferred to a plastic ultra-violet cuvette and its absorbance recorded at $515 \mathrm{~nm}$. Absorbance of a control containing $150 \mu \mathrm{L}$ of methanol with DPPH was recorded after every 12 samples were analyzed. Change in absorbance of each sample was computed as the difference between the control and sample readings.

Known concentrations of Trolox were used to prepare a standard curve with linear regression, which was used as a reference for comparing the sample extracts. The regression curve computed was $Y=892.98 X$, where $Y$ was the concentration of Trolox in $\mu \mathrm{M}$, and $X$ the change in absorbance of DPPH due to reduction by Trolox. Antioxidant activity of seed extracts was expressed as Trolox equivalents using the following equation; $Y=892.98$ $\times \Delta A_{515} \times\left(P M_{\text {Trolox }} / 1000\right) \times\left[\left(M_{\text {seed }}+\operatorname{Vol}_{M E O H} Y M_{\text {seed }}\right]\right.$, where $Y$ is the AOA in Trolox equivalents [micrograms Trolox equivalents per gram of dry seeds], $\Delta A_{515}$ is the change in absorbance due to antioxidants in the seed extract, $P M_{\text {Trolox }}$ is the molecular weight of Trolox ( $\left.250 \mathrm{~g} \cdot \mathrm{gmol}^{-1}\right), M_{\text {seed }}$ is the weight of seed samples in grams, $\mathrm{Vol}_{M E O H}$ is the volume of methanol in milliliters used for extraction.

Statistical analysis. Analysis of variance (ANOVA) was performed with the PROC GLM procedure from SAS (SAS, 1999). The model used in ANOVA was $Y_{i j k}=\mu+b_{i}+r_{j}+g_{k}+$ $\varepsilon_{i j k}$, where $Y_{i j k}$ is the observed value in the $\mathrm{j}^{\text {th }}$ replication of the $\mathrm{k}^{\text {th }}$ genotype in the $\mathrm{i}^{\text {th }}$ block, $\mu$ is the general mean, $b_{i}$ is the block effect, $r_{j}$ is the replication effect, $g_{k}$ is the effect of the $k^{\text {th }}$ genotype and $\varepsilon_{i j k}$ is the residual effect.

Comparisons among parents, $\mathrm{F}_{1} \mathrm{~s}$ and reciprocals were done following Griffing's (1956) Method I Model I, where all genotypes including parents were considered fixed. The diallel analysis of variance was done by the DIALLEL-SAS program developed by Zhang and Kang (1997). The sum of squares for the crosses was partitioned into general combining ability (GCA), specific combining ability (SCA), and reciprocal effects (RE). The RE were partitioned into maternal (MAT) and nonmaternal (NONM) effects following Cockerham's (1963) method using SAS codes adopted from Kang (2003).

Broad sense heritability was computed according to Hallauer and Miranda (1981), $H^{2}=2 \hat{\sigma}_{G C A}^{2} /\left(\hat{\sigma}^{2} / r+\hat{\sigma}_{S C A}^{2}+2 \hat{\sigma}_{G C A}^{2}\right)$. The GCA:SCA ratios with a theoretical maximum of unity were computed according to Baker (1978) as follows: GCA:SCA = $2 M S_{G C A} /\left(2 M S_{G C A}+M S_{S C A}\right)$; where $M S_{G C A}$ is the GCA mean square and $M S_{S C A}$ is the SCA mean square.

Generation means and variances were used to determine gene actions by performing scaling tests (Mather and Jinks, 1971). Three scaling tests were performed, $A=2 \overline{B C_{1}}-\overline{P 1}-\overline{F_{1}}, B=$ 
$2 \overline{B C_{2}}-\overline{P 2}-\overline{F_{1}}$, and $C=4 \overline{F_{2}}-2 \overline{F_{1}}-\overline{P 1}-\overline{P 2}$; where $\overline{P 1}, \overline{P 2}, F_{1}$, $\overline{F_{2}}, \overline{B C_{1}}$, and $\overline{B C_{2}}$ are the means of parents, $\mathrm{F}_{1}$ crosses, $\mathrm{F}_{2} \mathrm{~s}$, and backcross generations, respectively.

Joint scaling tests were performed using regression (Cavalli, 1952) to estimate mid-parent values (m), additive gene effects [a], dominance deviation [d] as well as nonallelic interactions (i.e., additive $\times$ additive [aa], additive $\times$ dominance [ad], and dominance $\times$ dominance [dd] epistatic effects).

The effective or minimum number of genes $\left(n_{E}\right)$ controlling antioxidant activity was estimated with the equation,

$$
n_{E}=\frac{(\overline{P 1}-\overline{P 2})^{2}}{\left[8\left(2 \sigma_{F_{2}}^{2}-\sigma_{B C_{1}}^{2}-\sigma_{B C_{2}}^{2}\right)\right]}
$$

where $\overline{P 1}$ and $\overline{P 2}$ and refer to means of the parents, $\sigma_{F}^{2}$, refers to the variance of $\mathrm{F}_{2}, \sigma^{2}{ }_{B C_{1}}$ and $\sigma^{2}{ }_{B C_{2}}$ are the variances of backcross generations with $\mathrm{P} 1$ and $\mathrm{P} 2$ as recurrent parents, respectively. The standard error of estimate for minimum number of genes was computed using the following formula (Lande, 1981):

$$
\begin{aligned}
& \sqrt{\operatorname{Var}\left(n_{E}\right)} \cong \sqrt{n_{E}^{2}}\left(\frac{4\left[\sigma_{P 1}^{2} / N_{P 1}+\sigma_{P 2}^{2} / N_{P 2}\right]}{[\overline{P 1}-\overline{P 2}]^{2}}+\right. \\
& \left.\frac{\left[8 \sigma_{F_{2}}^{4} / N_{F_{2}}-2 \sigma_{B C_{1}}^{4} / N_{B C_{1}}-2 \sigma_{B C_{2}}^{4} / N_{B C_{2}}\right]}{\left(2 \sigma_{F_{2}}^{2}-\sigma_{B C_{1}}^{2}-\sigma_{B C_{2}}^{2}\right)^{4}}\right)
\end{aligned}
$$

where, $\sigma_{\mathrm{P} 1}^{2}, \sigma_{\mathrm{P} 2}^{2}, \sigma_{F_{2}}^{2}, \sigma_{B C_{1}}^{2}$, and $\sigma_{B C_{2}}^{2}$ are variances of parents, $\mathrm{F}_{2} \mathrm{~s}$ and backcrosses. $N$ is the number of individuals in the generation corresponding to its subscript.

\section{Results and Discussion}

Diallel ANALYSIS. Significant differences among crosses were revealed by the ANOVA(Table 1). Diallel analysis showed highly significant GCA, SCA, and RE mean squares. The significance of both GCA and SCA implies that additive and dominance effects contributed to the genetic control of antioxidant activity in the lines used in this study. Results show that additive effects were more important than dominance effects since the mean square for GCA was greater than that for SCA (Table 1). According to Goffman and Becker (2001) the relative amount of GCA variance may have been overestimated since the parents used in this study were not randomly selected, but rather selected for extreme (highest and lowest) values of total AOA.

Combining abilities reported could be biased by the lack of independent distribution of genes in the parental lines as a result of the small number of lines used in the study (Baker, 1978). Despite the limitations mentioned above, information from this study is helpful in identifying the best sources of antioxidant activity among the lines used. Estimates of GCA were significant for all parents (Table 2). Parental lines with high AOA (ARK98348 and ARK95-356) exhibited large positive GCA effects, while the low AOAlines (ARK96-918 and LA92-180) had negative GCA effects. In addition, pigmented lines exhibited positive GCA while nonpigmented ones exhibited negative GCA. Therefore, there seems ity.
Table 1. Analysis of variance for antioxidant activity (AOA) in cowpea from a $4 \times 4$ complete diallel following Griffing's Method I.

\begin{tabular}{lrrrr}
\hline Source & df & Sum of squares & Mean squares & \multicolumn{1}{c}{ F } \\
\hline Block & 2 & 83459.3 & 41729.6 & 0.8 \\
Rep (Block) & 42 & 1295068.3 & 30835.0 & 0.7 \\
Crosses & 15 & 101719829.3 & 6781322.0 & $160.7^{* *}$ \\
$\quad$ GCA & 3 & 57158374.0 & 19052791.3 & $449.7^{* *}$ \\
SCA & 6 & 809269.0 & 134878.2 & $3.2^{* *}$ \\
RE & 6 & 33952320.8 & 5658720.1 & $133.6^{* *}$ \\
MAT & 3 & 33375098.7 & 11125033.0 & $262.6^{* *}$ \\
NONM & 3 & 186921.4 & 62307.1 & 1.5 \\
Error & 440 & 18640863.1 & 42365.6 & \\
\hline
\end{tabular}

$\overline{{ }^{z} \mathrm{GCA}}=$ general combining ability; SCA = specific combining ability; $\mathrm{RE}=$ reciprocal effects; $\mathrm{MAT}=$ maternal effects; $\mathrm{NONM}=$ nonmaternal effects.

** Significance at $P \leq 0.01$.

Table 2. Estimates of parental general combining ability (GCA) and maternal (MAT) effects for antioxidant activity (AOA) in cowpea genotypes used in a $4 \times 4$ complete diallel analysis.

\begin{tabular}{llrr}
\hline & Seed & \multicolumn{1}{c}{ MAT } \\
Parent & color & \multicolumn{1}{c}{ GCA } & \multicolumn{1}{c}{ MA3. } \\
\hline ARK98-348 (H) & Red & $353.1^{* *} \pm 11.1$ & $333.5^{* *} \pm 13.0$ \\
ARK95-356 (H) & Black & $49.2^{* *} \pm 11.1$ & $40.4^{* *} \pm 11.9$ \\
ARK96-918 (L) & Cream & $-177.3^{* *} \pm 11.1$ & $-214.9^{* *} \pm 13.0$ \\
LA92-180 (L) & Cream & $-225.0^{* *} \pm 11.1$ & $-159.0^{* *} \pm 12.1$ \\
\hline
\end{tabular}

${ }^{\mathrm{z}} \mathrm{H}=$ high AOA; $\mathrm{L}=$ low AOA.

** Significance at $P \leq 0.01$.

to be a strong relationship between seedcoat color and AOA. Both negative and positive GCA effects are of interest since they may permit breeding for different levels of AOA.

Specific combining ability effects were not significant for all crosses except ARK98-348 × LA92-180 (Table 3). These results indicate that nonadditive gene effects were significant in this cross. All crosses showed highly significant RE effects for AOA, especially those between pigmented and nonpigmented parents. The mean square for RE effects was partitioned into MAT and NONM effects (Tables 1-3). Maternal effects were highly significant (Tables 1 and 2) while NONM effects were not significant (Tables 1 and 3). These results indicate that reciprocal effects were mostly due to MAT since the NONM component of the RE was not significant.

The GCA:SCA ratio computed was 0.99 , which is near the theoretical maximum of unity. This provided further evidence for presence of additive gene action among the loci that control AOA (Baker, 1978). Heritability on an individual plant basis (broad sense) was estimated to be 0.87 . According to Bernardo (2002) individual plant measurements of quantitative traits are prone to

Table 3. Estimates of specific combining ability (SCA), reciprocal (RE), and nonmaternal (NONM) effects of crosses between cowpea genotypes exhibiting high $(\mathrm{H})$ and low $(\mathrm{L})$ antioxidant activ-

\begin{tabular}{lrrr}
\hline Cross & \multicolumn{1}{c}{ SCA } & \multicolumn{1}{c}{ RE } & \multicolumn{1}{c}{ NONM } \\
\hline ARK98-348 (H) $\times$ ARK95-356 (H) & $-2.8 \pm 20.6$ & $286.8^{* *} \pm 26.5$ & $-6.4 \pm 20.0$ \\
ARK98-348 (H) $\times$ ARK96-918 (L) & $24.7 \pm 24.5$ & $590.6^{* *} \pm 34.3$ & $42.2 \pm 22.1$ \\
ARK98-348 (H) $\times$ LA92-180 (L) & $-82.5^{* *} \pm 21.6$ & $456.7^{* *} \pm 28.7$ & $-35.8 \pm 20.5$ \\
ARK95-356 (H) $\times$ ARK96-918 (L) & $-37.3 \pm 21.4$ & $244.0^{* *} \pm 28.3$ & $-11.2 \pm 20.4$ \\
ARK95-356 (H) $\times$ LA92-180 (L) & $-0.7 \pm 21.0$ & $204.2^{* *} \pm 27.4$ & $17.7 \pm 35.2$ \\
ARK96-918 (L) $\times$ LA92-180 (L) & $38.5 \pm 21.1$ & $-25.0 \pm 27.6$ & $53.5 \pm 37.3$
\end{tabular}

***:Significance at $P \leq 0.05$ or 0.01 , respectively. 
large nongenetic effects, resulting in higher estimates of heritability. However, this high value suggests that improvement of AOA in cowpea can be realized through breeding if some of this genetic variation is additive. This estimate of heritability pertains to the conditions in this study and the four lines used, as they were not randomly selected. Some reports have referred to this kind of estimate (ratio of genetic variation to phenotypic variation) as repeatability when nonrandom genotypes are evaluated (Fehr, 1987).

Generation mean analysis. All $F_{1}$ hybrids had the same color as their female parent, and their levels of AOA were not significantly different from that of the female parent (Table 4). Crosses in which $\mathrm{F}_{1} \mathrm{~S}$ were significantly different from the higher parent were ARK98-348 $(\mathrm{H}) \times$ LA92-180 $(\mathrm{L})$ and ARK95-356 $(\mathrm{H}) \times$ LA92-180 (L), but still AOA levels were closer to the higher parent than the lower parent. Backcrosses were similar in color to their recurrent parents and also not significantly different in AOA.

Crosses involving pigmented and nonpigmented parents produced $\mathrm{F}_{2}$ and $\mathrm{F}_{2}$ reciprocal seeds of a slightly different shade than either parent. $F_{2}$ seeds from the cross between red (P1) and black (P2) lines were black, indicating dominance of the gene(s) responsible for black to that responsible for red seedcoat color (Table 4). Similar results were observed by Saunders (1959) and Calub (1968). Saunders (1959) reported that most of the common colors and color patterns of the cowpea seedcoat result from interactions between two or more genes. He stated that the gene responsible for black color is dominant to all but the purple seed color. Calub (1968) suggested that black is epistatic to all colors regardless of the presence of other color genes.

Antioxidant activity of $\mathrm{F}_{2}$ seeds from the cross ARK98-348 (H, red) $\times$ ARK95$356(\mathrm{H}$, black) was significantly different from that of the ARK98-348 parent but not significantly different from ARK95-356 parent. These results showed that factors controlling AOAin ARK95-356 (H, black) were dominant to those in ARK98-348 $(\mathrm{H}$, red), with dominance negative in relation to ARK98-348 $(\mathrm{H}$, red) since it exhibited more activity than ARK95-356 (H, black)

Crosses between pigmented (red or black) and nonpigmented (cream) lines showed dominance of pigmented lines over nonpigmented lines for both seedcoat color and AOA (Table 4), thus supporting the apparent relationship between seedcoat color and AOA. Pigmented lines seem to pos-
Table 4. Generation means and their standard errors for antioxidant activity (AOA) in cowpea seeds

\begin{tabular}{|c|c|c|c|c|}
\hline Generation $^{2}$ & Color $^{y}$ & Seeds (no.) & Mean $^{x}$ & $\overline{\mathrm{SE}}$ \\
\hline & \multicolumn{4}{|c|}{$A R K 98-348(P 1) \times A R K 95-356(P 2)$} \\
\hline $\mathrm{P} 1$ & $\operatorname{Red}(\mathrm{H})$ & 45 & $1346.3 \mathrm{a}$ & 255.2 \\
\hline $\mathrm{P} 2$ & $\operatorname{Black}(\mathrm{H})$ & 45 & $718.8 \mathrm{~d}$ & 97.3 \\
\hline $\mathrm{F}_{1}$ & Red & 30 & $1272.2 \mathrm{a}$ & 196.5 \\
\hline $\mathrm{F}_{1}^{\prime}$ & Black & 30 & $698.2 \mathrm{~d}$ & 158.0 \\
\hline $\mathrm{F}_{2}$ & Black & 192 & $836.6 \mathrm{c}$ & 160.5 \\
\hline $\mathrm{F}_{2}^{\prime}$ & Black & 201 & $764.5 \mathrm{~cd}$ & 143.6 \\
\hline $\mathrm{BC}_{1}$ & Red & 25 & $985.3 \mathrm{~b}$ & 499.2 \\
\hline \multirow[t]{2}{*}{$\mathrm{BC}_{2}$} & Black & 149 & $727.1 \mathrm{~d}$ & 184.7 \\
\hline & \multicolumn{4}{|c|}{ ARK98-348 (P1) × ARK96-918 (P2) } \\
\hline $\mathrm{P} 1$ & $\operatorname{Red}(\mathrm{H})$ & 45 & $1346.3 \mathrm{a}$ & 255.2 \\
\hline $\mathrm{P} 2$ & Cream $(\mathrm{L})$ & 44 & $202.3 \mathrm{~d}$ & 37.0 \\
\hline $\mathrm{F}_{1}$ & Red & 27 & $1378.8 \mathrm{a}$ & 659.9 \\
\hline $\mathrm{F}_{1}^{\prime}$ & Cream & 13 & $193.9 \mathrm{~d}$ & 35.7 \\
\hline $\mathrm{F}_{2}$ & Grayed red & 194 & $877.5 \mathrm{c}$ & 248.4 \\
\hline $\mathrm{F}_{2}^{\prime}$ & Grayed red & 200 & $846.0 \mathrm{c}$ & 207.5 \\
\hline $\mathrm{BC}_{1}$ & Red & 142 & $990.3 \mathrm{~b}$ & 218.5 \\
\hline \multirow[t]{2}{*}{$\mathrm{BC}_{2}$} & Cream & 165 & $173.6 \mathrm{~d}$ & 28.7 \\
\hline & \multicolumn{4}{|c|}{ ARK98-348 $(P 1) \times L A 92-180(P 2)$} \\
\hline $\mathrm{P} 1$ & $\operatorname{Red}(\mathrm{H})$ & 45 & $1346.3 \mathrm{a}$ & 255.2 \\
\hline $\mathrm{P} 2$ & Cream (L) & 45 & $174.4 \mathrm{e}$ & 27.4 \\
\hline $\mathrm{F}_{1}$ & Red & 23 & $1089.2 \mathrm{~b}$ & 340.3 \\
\hline $\mathrm{F}_{1}^{\prime}$ & Cream & 30 & $174.9 \mathrm{e}$ & 26.4 \\
\hline $\mathrm{F}_{2}$ & Ash gray & 209 & $786.5 \mathrm{~d}$ & 216.2 \\
\hline $\mathrm{F}_{2}^{\prime}$ & Ash gray & 208 & $920.0 \mathrm{c}$ & 138.5 \\
\hline $\mathrm{BC}_{1}$ & Red & 164 & $1063.4 \mathrm{~b}$ & 239.4 \\
\hline \multirow[t]{2}{*}{$\mathrm{BC}_{2}$} & Cream & 180 & $176.3 \mathrm{e}$ & 26.9 \\
\hline & \multicolumn{4}{|c|}{$A R K 95-356(P 1) \times A R K 96-918(P 2)$} \\
\hline $\mathrm{P} 1$ & Black (H) & 45 & $718.8 \mathrm{a}$ & 97.3 \\
\hline $\mathrm{P} 2$ & Cream (L) & 44 & $202.3 \mathrm{c}$ & 37.0 \\
\hline $\mathrm{F}_{1}$ & Black & 24 & $665.6 \mathrm{~b}$ & 57.9 \\
\hline $\mathrm{F}_{1}^{\prime}$ & Cream & 30 & $176.6 \mathrm{c}$ & 50.8 \\
\hline $\mathrm{F}_{2}$ & Black w/ white spots & 201 & $729.4 \mathrm{a}$ & 115.0 \\
\hline $\mathrm{F}_{2}^{\prime}$ & Black w/ white spots & 201 & $635.4 \mathrm{~b}$ & 91.6 \\
\hline $\mathrm{BC}_{1}$ & Black & 173 & $669.7 \mathrm{~b}$ & 130.9 \\
\hline \multirow[t]{2}{*}{$\mathrm{BC}_{2}$} & Cream & 147 & $191.3 \mathrm{c}$ & 76.1 \\
\hline & \multicolumn{4}{|c|}{ ARK95-356 (P1) × LA92-180 (P2) } \\
\hline $\mathrm{P} 1$ & Black $(\mathrm{H})$ & 45 & $718.8 \mathrm{ab}$ & 97.3 \\
\hline $\mathrm{P} 2$ & Cream (L) & 45 & $174.4 \mathrm{de}$ & 27.4 \\
\hline $\mathrm{F}_{1}$ & Black & 30 & $613.8 \mathrm{c}$ & 97.4 \\
\hline $\mathrm{F}_{1}^{\prime}$ & Cream & 27 & $207.0 \mathrm{~d}$ & 24.2 \\
\hline $\mathrm{F}_{2}$ & Black w/ white spots & 201 & $697.8 \mathrm{~b}$ & 114.8 \\
\hline $\mathrm{F}_{2}^{\prime}$ & Black w/ white spots & 175 & $734.8 \mathrm{a}$ & 102.3 \\
\hline $\mathrm{BC}_{1}$ & Black & 192 & $700.3 \mathrm{ab}$ & 119.5 \\
\hline \multirow[t]{2}{*}{$\mathrm{BC}_{2}$} & Cream & 87 & $147.1 \mathrm{e}$ & 19.9 \\
\hline & \multicolumn{4}{|c|}{ ARK96-918 $(P 1) \times L A 92-180(P 2)$} \\
\hline $\mathrm{P} 1$ & Cream $(\mathrm{L})$ & 41 & $202.1 \mathrm{a}$ & 30.6 \\
\hline $\mathrm{P} 2$ & Cream (L) & 45 & $174.4 \mathrm{bc}$ & 27.4 \\
\hline $\mathrm{F}_{1}$ & Cream & 28 & $200.1 \mathrm{a}$ & 18.8 \\
\hline $\mathrm{F}_{1}^{\prime}$ & Cream & 12 & $210.1 \mathrm{a}$ & 12.5 \\
\hline $\mathrm{F}_{2}$ & Cream & 197 & $168.5 \mathrm{c}$ & 25.2 \\
\hline $\mathrm{F}_{2}^{\prime}$ & Cream & 198 & $179.3 \mathrm{~b}$ & 25.6 \\
\hline $\mathrm{BC}_{1}$ & Cream & 147 & $167.3 \mathrm{c}$ & 20.4 \\
\hline $\mathrm{BC}_{2}$ & Cream & 160 & $166.2 \mathrm{c}$ & 20.7 \\
\hline
\end{tabular}

zP1 = female parent; $\mathrm{P} 2$ = male parent; $\mathrm{F}_{1}=1^{\text {st }}$ generation seeds; $\mathrm{F}_{1}{ }^{\prime}=1$ st generation seeds from reciprocal cross; $\mathrm{F}_{2}=2$ nd generation seeds; $\mathrm{F}_{2}^{\prime}=2$ nd generation seeds from reciprocal cross; $\mathrm{BC}_{1}=$ backcrosses to parent $1 ; \mathrm{BC}_{2}=$ backcrosses to parent 2 .

y $\mathrm{H}=$ high $\mathrm{AOA} ; \mathrm{L}=$ low $\mathrm{AOA}$

Means with same letter superscript are not significantly different by LSD at $P \leq 0.05$.

sess favorable factors that enhance AOA. The inheritance pattern among factors governing AOA in the lines studied is similar to that of factors responsible for seedcoat color, hence indicating a very strong relationship between these traits. 
Table 5. Estimates of mid-parent (m), additive [a], dominance [d], and nonallelic interaction ([aa], [ad], and [dd]) pooled effects and their standard errors for crosses between cowpea genotypes exhibiting high and low antioxidant activity (AOA).

\begin{tabular}{|c|c|c|c|}
\hline Parameter $^{\mathrm{z}}$ & & Estimate & SE \\
\hline \multicolumn{4}{|c|}{$A R K 98-348(H) \times A R K 95-356(H)$} \\
\hline $\mathrm{m}$ & & $959.2^{* * *}$ & 29.9 \\
\hline [a] & & $293.1^{* *}$ & 19.6 \\
\hline [d] & & $-100.6^{* *}$ & 36.4 \\
\hline \multirow[t]{3}{*}{ Scaling test } & A & -645.0 & 1035.1 \\
\hline & B & -536.9 & 429.5 \\
\hline & $\mathrm{C}$ & -1263.3 & 800.8 \\
\hline \multicolumn{4}{|c|}{$A R K 98-348(H) \times A R K 96-918(L)$} \\
\hline $\mathrm{m}$ & & $1755.2^{* * *}$ & 86.4 \\
\hline [a] & & $572.4^{* *}$ & 26.8 \\
\hline [d] & & $-3278.6^{* *}$ & 221.2 \\
\hline [aa] & & $-1079.1^{* *}$ & 78.0 \\
\hline [ad] & & $532.3^{* *}$ & 79.4 \\
\hline [dd] & & $2437.0^{* * *}$ & 162.3 \\
\hline \multirow[t]{3}{*}{ Scaling test } & A & -744.5 & 831.0 \\
\hline & B & $-1233.9^{*}$ & 663.4 \\
\hline & $\mathrm{C}$ & -796.2 & 1664.7 \\
\hline \multicolumn{4}{|c|}{ ARK98-348 $(H) \times L A 92-180(L)$} \\
\hline $\mathrm{m}$ & & $1650.5^{* *}$ & 70.1 \\
\hline [a] & & $586.0^{* * *}$ & 22.6 \\
\hline [d] & & $-2271.1^{* *}$ & 178.9 \\
\hline [aa] & & $-911.9^{* * *}$ & 63.3 \\
\hline [ad] & & $606.9^{* *}$ & 64.7 \\
\hline [dd] & & $1174.1^{* *}$ & 128.7 \\
\hline \multirow[t]{3}{*}{ Scaling test } & A & -308.7 & 640.5 \\
\hline & B & $-911.1^{*}$ & 428.8 \\
\hline & $\mathrm{C}$ & -553.1 & 1130.0 \\
\hline \multicolumn{4}{|c|}{$A R K 95-356(H) \times A R K 96-918(L)$} \\
\hline $\mathrm{m}$ & & $1479.2^{* *}$ & 41.3 \\
\hline [a] & & $258.2^{* *}$ & 12.9 \\
\hline [d] & & $-2081.6^{* *}$ & 104.8 \\
\hline [aa] & & $-1003.5^{* *}$ & 37.1 \\
\hline [ad] & & $436.3^{* *}$ & 37.7 \\
\hline [dd] & & $1011.0^{*}$ & 74.9 \\
\hline \multirow[t]{3}{*}{ Scaling test } & A & -45.0 & 285.2 \\
\hline & B & $-485.3^{* *}$ & 189.7 \\
\hline & $\mathrm{C}$ & 665.2 & 485.6 \\
\hline \multicolumn{4}{|c|}{$A R K 95-356(H) \times L A 92-180(L)$} \\
\hline $\mathrm{m}$ & & $1568.5^{* *}$ & 42.1 \\
\hline [a] & & $272.2^{* *}$ & 12.0 \\
\hline [d] & & $-2411.2^{* *}$ & 108.6 \\
\hline [aa] & & $-1149.3^{* *}$ & 38.0 \\
\hline [ad] & & $548.8^{* * *}$ & 38.2 \\
\hline [dd] & & $1238.9^{* *}$ & 76.6 \\
\hline \multirow[t]{3}{*}{ Scaling test } & A & 68.0 & 275.9 \\
\hline & B & $-494.0^{* *}$ & 108.7 \\
\hline & $\mathrm{C}$ & 670.4 & 508.0 \\
\hline \multicolumn{4}{|c|}{$A R K 96-918(L) \times L A 92-180(L)$} \\
\hline $\mathrm{m}$ & & $172.4^{* *}$ & 3.5 \\
\hline [a] & & $7.6^{* *}$ & 2.0 \\
\hline [d] & & -0.4 & 4.7 \\
\hline \multirow[t]{3}{*}{ Scaling test } & A & -67.7 & 54.3 \\
\hline & B & -42.2 & 53.1 \\
\hline & $\mathrm{C}$ & -102.7 & 115.2 \\
\hline
\end{tabular}

${ }_{\mathrm{z}} \mathrm{H}=$ high $\mathrm{AOA} ; \mathrm{L}=$ low $\mathrm{AOA} ; \mathrm{m}=$ mid-parent value of $\mathrm{AOA} ;[\mathrm{a}]=$ pooled additive gene effects; $[\mathrm{d}]=$ pooled dominance gene effects; [aa] = additive $\times$ additive interaction gene effects; $[\mathrm{ad}]=$ additive $\times$ dominance interaction gene effects; $[\mathrm{dd}]=$ dominance $\times$ dominance interaction gene effects; $\mathrm{A}=$ test for significance of additive $\times$ additive epistatic effects; $\mathrm{B}=$ test for significance of additive $\times$ dominance epistatic effects; $\mathrm{C}=$ test for significance of dominance $\times$ dominance epistatic effects;

*,**Significance at $P \leq 0.05$ or 0.01 , respectively.
GENE EFFECTS. Scaling tests (A, B, and C) were not significant in the crosses ARK98-348 (H) ×ARK95-356 (H) and ARK96-918 (L) $\times$ LA92-180 (L), implying that the additive-dominance model was satisfactory in explaining the variation among generations (Table 5). A three-parameter model (m, [a] and [d]) was fitted for these crosses and all parameters involved were significant. Greater additive than dominance effects were observed in cross ARK98-348 $(\mathrm{H}) \times$ ARK95-356 $(\mathrm{H})$ which involved both pigmented parents.

Some of the scaling tests in crosses ARK98-348 (H) ×ARK96$918(\mathrm{~L})$, ARK98-348 (H) × LA92-180 (L), ARK95-356 (H) $\times$ ARK96-918 (L), and ARK95-356 (H) × LA92-180 (L) were significant (Table 5). Therefore, a simple additive-dominance model would not be adequate in explaining variation among generations from these crosses (Kearsey and Pooni, 1996).

Failure of the simple additive-dominance model to fit the data in some crosses (Table 5) implies that some of the assumptions on which the model was constructed were not valid (Mather and Jinks, 1977). Scaling tests (A, B, and C) assume simple autosomal inheritance of the factors concerned. Therefore, they do not hold if differential viability, maternal effects, and nonallelic (epistatic) interaction between genes exist (Kearsey and Pooni, 1996). A six-parameter model including nonallelic interaction was fitted, using the joint scaling test, to determine the type and magnitude of gene action involved in the crosses in which the simple additive-dominance model was inadequate (Cavalli, 1952). All the effects, including nonallelic interactions ( $\mathrm{m}$, [a], [d], [aa], [ad] and [dd]), were significant (Table 5). This confirmed the presence of nonallelic interactions, thus explaining the failure of the simple additive-dominance model observed in these crosses.

The sign of the dominance effects [d] was positive while that of dominance $\times$ dominance interaction [dd] was negative for crosses ARK98-348 (H) ×ARK96-918 (L), ARK98-348 (H) × LA92-180 (L), ARK95-356 (H) × ARK96-918 (L), and ARK95-356 (H) $\times$ LA92-180 (L) (Table 5). This suggested presence of duplicate gene interactions in these crosses (Mather and Jinks, 1977).

The minimum number of factors or genes controlling AOA was estimated to be $4.9 \pm 0.3$ (Table 6). This estimate is in the range proposed by Lande (1981) who reported that the effective or minimum number of freely-segregating genetic factors involved in producing a large difference between populations in a quantitative trait is estimated to be $\approx 5$ or 10 . Estimates from crosses ARK98-348 $(\mathrm{H}) \times$ ARK95-356 $(\mathrm{H})$ and ARK96-918 (L) $\times$ LA92-80 (L) were less than one, because the range of genetic variance in $\mathrm{F}_{2}$ generations exceeded the mean difference of the parental generations. Hence the method used for estimation was of little value in these two crosses.

Table 6. Estimates of the minimum number of genes controlling antioxidant activity (AOA) in crosses of cowpea genotypes exhibiting high or low AOA.

\begin{tabular}{lcc}
\hline Cross & No. of genes & SE \\
\hline ARK98-348 $(\mathrm{H}) \times$ ARK95-356 $(\mathrm{H})^{\mathrm{z}}$ & $<1$ & \\
ARK98-348 $(\mathrm{H}) \times$ ARK96-918 $(\mathrm{L})$ & 2.2 & 0.2 \\
ARK98-348 $(\mathrm{H}) \times$ LA92-180 $(\mathrm{L})$ & 4.5 & 0.3 \\
ARK95-356 $(\mathrm{H}) \times$ ARK96-918 $(\mathrm{L})$ & 9.5 & 0.6 \\
ARK95-356 $(\mathrm{H}) \times$ LA92-180 $(\mathrm{L})$ & 3.2 & 0.2 \\
ARK96-918 $(\mathrm{L}) \times$ LA92-180 $(\mathrm{L})$ & $<1$ &
\end{tabular}

z $\mathrm{H}=$ high AOA; $\mathrm{L}=$ low AOA. 


\section{Conclusions}

There is a very strong relationship between AOA and seedcoat color. Pigmented varieties of cowpea possess favorable factors that enhance AOA. Factors governing high AOA in cowpea seeds appear to be the same factors responsible for seedcoat color, with apparent pleiotropic effects. The inheritance pattern of factors governing AOA is similar to that of factors governing seedcoat color.

There are varying levels of AOA among cowpea varieties. Color factors appear to impart these differences; therefore, higher levels of activity can be obtained utilizing colored cowpea varieties as parents.

Antioxidant activity is highly heritable in cowpea, as indicated by a large estimate of heritability. Therefore, selection for this trait can be achieved with minimal effort using pigmented varieties as preferred parental material.

\section{Literature Cited}

Amarowicz, R., U.N. Wanasundara, M. Karamac, and F. Shahidi. 1996. Antioxidant activity of ethanolic extract of mustard seed. Nuhrung 40:261-263.

Baker, R.J. 1978. Issues in diallel analysis. Crop Sci. 18:533-536.

Barlow, S.M. 1990. Toxicological aspects of antioxidants used as food additives, p. 253-307. In: B.J.F. Hudson (ed.). Food antioxidants. Elsevier, London.

Benavente-Garcia, O., J. Castillo, F.R. Marin, A. Ortuno, and J.A.D. Rio. 1997. Use and properties of citrus flavonoids. J. Agr. Food Chem. 45:4505-4515.

Beninger, C.W., G.L. Hosfield, and M.G. Nair. 1998. Flavonol glycosides from a new manteca-type dry bean (Phaseolus vulgaris L.). J. Agr. Food Chem. 46:2906-2910.

Bernardo, R. 2002. Breeding for quantitative traits in plants. Stemma Press, Woodbury, Minn.

Brand-Williams, W., M.E. Cuvelier, and C. Berset. 1995. Use of free radical method to evaluate antioxidant activity. Lebensmittel Wissenschaft Technologie 28:25-30.

Branen, A.L. 1975. Toxicology and biochemistry of butylated hydroxyl anisole and butylated hydroxyl toluene. J. Amer. Oil Chem. Soc. 52:59-63.

Calub, A.G. 1968. Inheritance of seed color and color pattern in Vigna sinensis (Linn.) cowpeas (Vigna unguiculata L. Walp): Abstracts of World Literature. Vol. 1:1950-1973. The International Grain Legume Information Centre, IITA, Ibadan, Nigeria. p.14.

Cavalli, L.L. 1952. An analysis of linkage in quantitative inheritance, p. 135-144. In: E.C.R. Reeve and C.H. Waddington (eds.). Quantitative inheritance. Her Majesty's Stationery Office, London.

Chang, L.W., W.J. Yen, S.C. Huang, and P.D. Duh. 2002. Antioxidant activity in sesame coat. Food Chem. 78:347-354.

Cockerham, C.C. 1963. Estimation of genetic variances, p. 53-94. In:W.D. Hanson and H.F. Robinson (eds.). Statistical genetics and plant breeding. Natl. Acad. Sci.-Natl. Research Council, Washington, D.C.

Comis, D. 2000. Bringing you better beans. Agr. Res. Mag. 48(9):1417.

Cook, N.C. and S. Samman. 1996. Flavonoids-chemistry, metabolism, cardio protective effects, and dietary sources. Nutr. Biochem. 7:66-76.

Fehr, W.R. 1987. Principles of cultivar development Vol. 1: Theory and technique. Macmillan, New York.

Fery, R.L. 1985. The genetics of cowpea: Areview of the world literature, p. 25-62. In: S.R. Singh and K.O. Rachie. (eds.). Cowpea research, production and utilization. Wiley, Chichester, U.K.

Food and Nutrition Board. 1998. Dietary reference intakes: Proposed definition and plan for review of dietary antioxidants and related compounds. Natl. Acad. Press, 12 Feb. 2004. http://www4.nas.edu/ IOM/IOMHome.nsf/Pages/Ongoing+studies.

Goffman, F.D. and H.C. Becker. 2001. Diallel analysis for tocopherol contents in seeds of rapeseed. Crop Sci. 41:1072-1079.

Griffing, B. 1956. Concept of general combining and specific combin- ing ability in relation to diallel crossing systems. Aust. J. Biol. Sci. 9:463-493.

Hallauer, A.R. and J.B. Miranda Fo. 1981. Quantitative genetics in maize breeding. Iowa State Univ. Press, Ames.

Hertog, M.G.L. and P.C.H. Hollman. 1996. Potential health effects of dietary flavonoid quercetin. European J. Clinical Nutr. 50:63-64.

Huang, M.T. and T. Ferraro. 1992. Phenolic compounds in food and cancer prevention, p. 318. In: M.T. Huang, C.T. Ho, and C.Y. Lee. (eds.). Phenolic compounds in food and their effects on health II. Antioxidants and cancer prevention. ACS Symp. Ser. 507, Amer. Chem. Soc., Washington, D.C.

Ito, N., A. Higawara, M. Shibata, T. Ogiso, and S. Fukushima. 1983. Induction of squamous cell carcinoma in the stomach of F344 rats treated with butylated hydroxyanisole. Gann Manographe Cancer Res. 73:332-334.

Kang, M.S. 2003. Handbook of formulas and software for plant geneticists and breeders. Food Products Press, Binghamton, N.Y.

Kearsey, M.J. and H.S. Pooni. 1996. The genetic analysis of quantitative traits. Chapman \& Hall, London.

Klein, B.P. and A.C. Kurilich. 2000. Processing effects on dietary antioxidants from plant foods. HortScience 35:580-584

Koleva, I.I., T.A. van Beek, J.P.H. Linssen, A. de Groot, and L.N. Evstatieva. 2002. Screening of plant extracts for antioxidant activity: A comparative study on three testing methods. Phytochem. Anal. 13:8-17.

Lande, R. 1981. The minimum number of genes contributing to quantitative variation between and within populations. Genetics 99:541-553.

Lentner, M. and T. Bishop. 1993. Experimental design and analysis. Valley Book, Blacksburg, Va.

Mather, K. and J.L. Jinks. 1971. Biometrical genetics. Cornell Univ. Press, Ithaca, N.Y.

Mather, K. and J.L. Jinks. 1977. Introduction to biometrical genetics. Cornell Univ. Press, Ithaca, N.Y.

Messina, M.J. 1999. Legumes and soybeans: Overview of their nutritional profiles and health effects. Amer. J. Clinical Nutr. 70(suppl.):439S$450 \mathrm{~S}$.

Morello, M.J., F. Shahidi, and C.T. Ho. 2002. Free radicals in foods: Chemistry, nutrition, and health effects. ACS Symp. Ser. 807. Amer. Chem. Soc., Washington, D.C.

Narasinga Rao, B.S. 1995. Bioactive phytochemicals in Indian foods. Nutr. Found. India Bul. 16(1).

Niki, E. and N. Noguchi. 2000. Evaluation of antioxidant capacity. What capacity is being measured by which method? Intl. Union of Biochem. Mol. Biol. Life 50:323-329.

Nzaramba, N.M., D.C. Scheuring, A.L. Hale, and J.C. Miller, Jr. 2003. Antioxidant activity in cowpea determined on a single-seed basis. HortScience 38:1298. (Abstr.).

Robards, K., P.D. Prenzler, G. Tucker, P. Swatsitang, and W. Glover. 1999. Phenolic compounds and their role in oxidative processes in fruits. Food Chem. 66:401-436.

SAS, 1999. SAS software version 8.0. SAS Institute, Cary, N.C.

Saunders, A.R. 1959. Inheritance in cowpea (Vigna sinensis Endl.). 1. Color of the seed coat. S. Afr. J. Agr. Sci. 2:285-306.

Shahidi,F. 2002. Antioxidants in plants and oleaginous seeds. p. 162-175. In: M.J. Morello, F. Shahidi, and C.T. Ho (eds.). Free radicals in food: Chemistry, nutrition, and health effects. Am. Chem. Soc., Washington, D.C.

Simon, W.P. 1997. Plant pigments for color and nutrition. HortScience 32:12-13.

Troszyńska, A., I. Estrella, M.L. López-Amóres, and T. Hernández. 2002. Antioxidant activity of pea (Pisum sativum L.) seed coat acetone extract. Lebensmittel Wissenschaft Technologie 35:158-164.

Velioglu, Y.S., G. Mazza, L. Gao, and B.D. Oomah. 1998. Antioxidant activity and total phenolics in selected fruits, vegetables, and grain products. J. Agr. Food Chem. 6:4113-4117.

Warrington, R.T., A.L. Hale, D.C. Scheuring, D.W. Whitaker, T. Blessington, and J.C. Miller, Jr. 2002. Variability for antioxidant activity in cowpea [Vigna unguiculata (L.) Walp.] as influenced by genotype and postharvest rehydration. HortScience 37:738. (Abstr.).

Zhang, Y. and M.S. Kang. 1997. DIALLEL-SAS: A SAS program for Griffing's diallel analyses. Agron. J. 89:176-182. 